\title{
INDEX OF PERFORATION OF PROCEDURE/SURGICAL GLOVES USED BY WORKERS IN THE PURGING OF A MATERIAL AND STERILIZATION CENTER
}

\author{
Júnnia Pires de Amorim Trindadeㄹ, Joyce Rutyelle da Serra², Anaclara Ferreira Veiga Tipple 3
}

\footnotetext{
${ }^{1}$ Master's student, Programa de Pós-Graduação em Enfermagem, Universidade Federal de Goiás (UFG). Goiânia, Goiás, Brazil. E-mail: junniatrindade@gmail.com

2 Nurse, UFG. Goiânia, Goiás, Brazil. E-mail: joyce--ruivinha@outlook.com

${ }^{3}$ Ph.D. in Nursing. Professor, Escola de Enfermagem, UFG. Goiânia, Goiás, Brazil. E-mail: anaclara.fen@gmail.com
}

\begin{abstract}
The objectives of this study were to identify the types of gloves the nursing team uses for the manual cleaning of health products and to identify the perforation rates in procedure/surgical gloves used for this purpose. Cross-sectional and descriptive, descriptive study with quantitative approach was developed at a large hospital in Goiânia, Goiás, Brazil. In total, 300 procedure/surgical gloves (Group A), 100 procedure and 100 new surgical gloves (Group B), and six nitrile gloves (Group C) were analyzed. Among the gloves in Group A, $135(45.0 \%)$ were perforated. Superposition of gloves did not prevent perforations and, the longer they were used, the higher the index of perforation $(\mathrm{p}<0.05)$. No perforations were identified in Group B, whereas there were four perforations in 48 hours of use in Group C. This study reinforces the idea that procedure/surgical gloves are inappropriate for cleaning health products, representing an ineffective barrier for the safety of workers.
\end{abstract}

DESCRIPTORS: Sterilization. Occupational risks. Surgical gloves.

\section{ÍNDICE DE PERFURAÇÃO DE LUVAS DE PROCEDIMENTO/CIRÚRGICA UTILIZADAS POR TRABALHADORES DO EXPURGO DE UM CENTRO DE MATERIAL E ESTERILIZAÇÃO}

RESUMO: Os objetivos foram identificar os tipos de luvas utilizadas pela equipe de enfermagem para a limpeza manual de produtos para a saúde e identificar os índices de perfurações em luvas de procedimento/cirúrgicas utilizadas para esta atividade. Estudo transversal e descritivo, com abordagem quantitativa, realizado em um hospital de grande porte em Goiânia, Goiás, Brazil. Foram avaliadas 300 luvas de procedimento/cirúrgicas (grupo A), 100 luvas de procedimento e 100 cirúrgicas novas (grupo B) e seis luvas nitrílicas (grupo C). Entre as luvas do grupo A, 135 (45,0\%) estavam perfuradas. Sobreposições de luvas não impediram as perfurações e quanto maior o tempo de uso, maior o índice de perfuração $(\mathrm{p}<0,05)$. Não houve perfurações no grupo B e no C identificou-se quatro perfurações em 48 horas de uso. O estudo reforça que as luvas cirúrgicas/procedimento são inadequadas para o processo de limpeza manual de produtos para a saúde, constituindo uma barreira ineficaz na segurança dos trabalhadores.

DESCRITORES: Esterilização. Riscos ocupacionais. Luvas cirúrgicas.

\section{ÍNDICE DE PERFORACIÓN DE GUANTES DE PROCEDIMENTO/ QUIRÚRGICO UTILIZADO POR LOS TRABAJADORES DE PURGA DE UN CENTRO DE MATERIAL Y ESTERILIZACIÓN} RESUMEN: Se objetivó identificar los tipos de guantes utilizados por el equipo de enfermería para limpieza manual de productos para la
salud y los índices de perforaciones en guantes de procedimiento/quirúrgicos utilizados en esta actividad. Estudio transversal, descriptivo,
cuantitativo, realizado en hospital de gran porte de Goiânia, Goiás, Brazil. Fueron evaluados 300 guantes de procedimiento/quirúrgicos
(grupo A), 100 guantes de procedimiento y 100 quirúrgicos nuevos (Grupo B) y seis guantes de nitrilo (Grupo C). Entre los guantes del
grupo A, 135 ( $45,0 \%$ ) estaban perforados. La superposición de guantes no impidió las perforaciones; y a mayor tiempo de uso, mayor
resultó el índice de perforación (p<0,05). No hubo perforaciones en el grupo B. En el C se identificaron cuatro perforaciones en 48 horas de
uso. El estudio refuerza que los guantes de procedimiento/quirúrgicos son inadecuados para el proceso de limpieza manual de productos
para la salud, constituyendo una barrera ineficaz para la seguridad del trabajador.

DESCRIPTORES: Esterilización. Riesgos laborales. Guantes quirúrgicos. 


\section{INTRODUCTION}

Occupational accidents are the most documented occupational health problems around the world. Even when considering the underreporting or insufficient registering of accidents, it is known that the biological risk is the most common among health professionals. ${ }^{1-2}$ This risk involves possible contact with biological material, such as blood or other organic fluids, which can transmit pathogenic biological agents that cause damage to the workers' health. ${ }^{3}$

Literature review ${ }^{4}$ identified that three virus (HBV, HCV and HIV) are responsible for most cases of occupational infections, due to their prevalence in the parents and the severity of the infections they cause. Nevertheless, in the studies analyzed, in total, 60 pathogenic agents were identified associated with occupational risk. In that sense, accidents involving biological material represent a big problem among health workers, who can be exposed through percutaneous inoculation, through needles or cutting objects, besides direct contact with intact and nonintact skin and mucosa. ${ }^{5-6}$

The Material and Sterilization Center (MSC) is defined as a functional unit for the processing of health products (PHP) at health services, following the steps: cleaning, conditioning, sterilization, storage and distribution..$^{7-8}$

Clearing in the PHP removes the organic material and reduces the microbial load. This is the most important phase of the processing. ${ }^{9-10}$ The cleaning can be manual or automated. Manual cleaning is done using detergent solution and friction using hard and soft brushes, followed by running or pressurized water. This type of cleaning comes with limitations, such as the lack of uniformity in the execution by different professionals, low productivity and biological and chemical occupational risks. ${ }^{8}$

To handle PHP contaminated with biological material, the professionals need to adopt safety measures. The use of individual protection equipment (IPE) in the cleaning process is fundamental in view of the exposure to blood splatters or piercing and cutting accidents. ${ }^{11-12}$ The following IPE is recommended for the manual cleaning of PHP: high nitrile or butyl gloves, impermeable long-sleeved gown, cap, facial protection or mask and protective glasses, plastic or impermeable boots. ${ }^{7-8}$

Protective equipment should be offered to the workers in view of the risk involved. ${ }^{13}$ Nitrile/butyl gloves are recommended for the manual cleaning of $\mathrm{PHP},{ }^{10}$ as they are made out of synthetic rubber, have good wear durability and are highly resistant to corrosive products, granting mechanical and chemical protection to the worker. Latex gloves, on the other hand, should not be used for manual cleaning due to their limited resistance to corrosive products and low mechanical protection. ${ }^{8}$

In one study, most of the MSC workers in the state of Goiás did not use the IPE recommended for the manual cleaning of the products when accidents happened during which hands and fingers were affected. In addition, the purging workers were using procedure gloves during PHP cleaning. ${ }^{13}$ The authors found that, among the 33 accident victims, 31 (93.9\%) were not using the recommended IPE. Most of the accidents involved piercing-cutting devices during manual cleaning. ${ }^{14}$

In another study involving 64 workers from MSC of 12 health institutions, it was identified that, even when thick gloves were available $(90.5 \%)$ and their importance was acknowledged (61.9\%), adherence to these gloves was low (33.3\%). Sometimes, IPE causes discomfort due to the reduced tactile sensitivity, increased body temperature and difficulty to move, demanding perseverance and recognition of its usage benefits. ${ }^{15}$

One accident involving a nursing student during PHP washing was identified in a study, which also verified that the student was not using the gloves indicated for that task. ${ }^{16}$

This study intends to contribute to understand the extent of the biological risk nursing workers engaged in the manual cleaning of PHP contaminated with organic secretions are exposed to and to discuss this practice, which is still predominant in different regions of Brazil. Its objectives were to: identify the types of gloves the nursing team uses for the manual cleaning of health products and to identify the perforation rates in procedure/surgical gloves used for this purpose.

\section{METHOD}

Cross-sectional and descriptive study with quantitative approach was undertaken at an MSC of a large teaching hospital in Goiânia, Goiás, Brazil where, during the study period, equipment cleaning was done only manually. This study is part of the project "Biological risk related to the processing of dental-medical-hospital products at a teaching hospital in Goiânia: implications for workers and users", with the approval of the institution's Ethics 
Committee for Medical Research involving Humans and Animals (protocol 167/ 2011). The data were collected in two phases:

Phase I: intended to identify the types of gloves used for the manual cleaning of PHP, a step needed to define the assessment of the gloves the workers were using at the service. This phase was undertaken between August and December 2011 through direct observation of the workers during the cleaning process of the PHP, focused on observing the type of gloves used. All workers engaged in purging were included. The observations took place twice a week, on the days general surgeries were done, and therefore involving a large equipment volume for cleaning. The hours when the demand for the service's work peaked were chosen, i.e. from 11h30min till 13h30min and from 17h30min till 19h. For the observations, one researcher stood in the circulation corridor outside the MSC, which has large glass windows and shows the entire internal environment.

At the end of each observation period, each professional was contacted individually and informed about the study objectives and the observation done. The workers were invited to participate and those who agreed signed the Free and Informed Consent Term. In case of refusal, the data were discarded.

Phase II: assessment of perforation rates of the surgical/procedure gloves used for the manual cleaning of PHP. Data collection between September and December 2012. The following groups of gloves were evaluated:

Group A: gloves used by members of the service team for manual cleaning. The sample was calculated based on the monthly glove consumption in the purging activity, with a $95 \%$ confidence interval, indicating a sample of 278 gloves. In total, 300 gloves were analyzed, independently of the type (surgical or procedure). As verified, most of the team members used more than one glove on each hand, ranging between two and four. Thus, when taking off the glove, the team member was asked to indicate the approximate length of use and place the glove in a plastic bag, identified in the order of removal. The most external glove was considered as "number 1" and so forth;

Group B (control 1 - integrity of new gloves): the number of gloves contained in a closed glove was analyzed, corresponding to 100 procedure gloves and 100 surgical gloves from the same brand the team used. A proportion was established in terms of size, in view of the usage frequency ob- served in group A, corresponding to 40 gloves of size medium (M), 30 large $(\mathrm{G})$ and 30 small (P);

Group C (control 2 - gold standard for manual cleaning): six thick nitrile gloves used by $4^{\text {th }}$-term students from the undergraduate nursing program during the study. The number corresponds to the gloves made available during the study period, as nitrile gloves are not disposable, but processed for reuse after each use. These gloves are compulsory in the routine practical classes of nursing students at the purging service. The teaching institution offers them and, therefore, the students were obliged to use them.

To assess the nitrile gloves, the length of use by the students on the respective practical activity days was considered. After the evaluation, intact gloves were submitted to the processing protocol (standardized in the subject), which consisted of cleaning, followed by disinfection using $70 \%$ alcohol and storage for the next use. Perforated gloves were replaced by new pairs of the same brand and size.

Procedure to assess the gloves (Groups A, B and C): 1) Appropriate garment of the researcher to access the purging area (cloak, impermeable gown, mask and glasses, closed shoes and think rubber gloves); 2) Collection of the gloves in bags for infectious waste, identified according to the order of use, length of use and hand (right or left); 3) Prewashing of the gloves in running water; 4) Dilution of methylene blue at $1.0 \mathrm{ml}$ for $1000 \mathrm{ml}$ of water; 5 ) Filling of the gloves with the volume respective to the size; 6) Application of mild hand compression and then of the fingers one by one; 7) Completion of a data collection tool that addressed the items: glove type (surgical or procedure), batch, date, start and end date of glove use and illustration of the hands to mark the perforation points; 8) Emptying of the gloves and disposal in container for infectious waste (milk-white bag with symbol of infectious).

To assess the gloves in groups $\mathrm{A}$ and $\mathrm{C}$ at the end of the activities, the researcher put on the garment to access the purging service and asked for the gloves. At the end of the data collection, the gloves from group B were assessed at the purging service.

The perforation index was assessed through visual inspection and, to make any perforations easier to see, the solution of methylene blue at 1.0 $\mathrm{ml}$ in $1000 \mathrm{ml}$ of water was used. The volumes to fill the gloves were determined after preliminary testing of the different sizes (S, M and L), considering two centimeters below the opening of the glove as the limit. Points were considered perforations when water leaked after mild compression, first of the 
palm and then of the fingers one by one. The leakage test adopted was indicated as the best option in a study that assessed the efficacy of the tests used to detect perforations in surgical gloves. ${ }^{17}$

The data were processed in the software Statistical Package for the Social Sciences (SPSS), version 19.0. To compare groups $\mathrm{A}$ and $\mathrm{B}$, the chi-squared test $\left(\mathrm{x}^{2}\right)$ was used and $p$-value $<0.05$ were considered statistically significant.

\section{RESULTS}

Initially, the gloves the workers were using were identified and, at the end of phase I, it was verified that, among the 54 observations, 53
(98.1\%), workers used surgical and/or procedure gloves for the manual cleaning, with the common use of different types on top of each other and, in one observation, the use of thick gloves was identified $(1.8 \%)$.

In view of the predominant use of surgical and procedure gloves for the manual cleaning of the PHP, the gloves were assessed and the sample size (300 gloves) was obtained as the gloves were made available on 75 opportunities (the same worker offered gloves more than once during the study). Thus, considering the gloves the workers were using, 172 procedure gloves were collected and 128 surgical gloves. Of these, 135 (45.0\%; 95\% CI: 39.5-50.7) were perforated.

Table 1 - Perforation index per glove type in group A (procedure/surgical) during the manual cleaning process of health products at the purging service of a Material and Sterilization Center of a Teaching Hospital. Goiânia-GO, Brazil, 2012

\begin{tabular}{|c|c|c|c|c|c|c|c|c|}
\hline \multirow{3}{*}{ Type of glove } & \multicolumn{4}{|c|}{ Perforation index } & \multirow[b]{2}{*}{ Total } & & \multirow{3}{*}{$X^{2 *}$} & \multirow{3}{*}{$\mathrm{p}$} \\
\hline & & Yes & & No & & & & \\
\hline & $\mathbf{n}$ & $\%$ & $\mathbf{n}$ & $\%$ & $\mathbf{n}$ & $\%$ & & \\
\hline Procedure & 76 & 44.2 & 96 & 55.8 & 172 & 57.5 & & \\
\hline Surgical & 59 & 46.1 & 69 & 53.9 & 128 & 42.5 & & \\
\hline Total & 135 & 45.0 & 165 & 55.0 & 300 & 100.0 & 0.108 & 0.743 \\
\hline
\end{tabular}

*Chi-square test

Among the gloves assessed in group A, 172 (57.5\%) procedure and $128(42.5 \%)$ surgical gloves, no statistically significant difference was found, that is, there is no difference between the procedure and surgical gloves with regard to the perforation index.

Of all perforated gloves $(n=135,45.0 \%$ of the sample), the highest percentage was identified in the gloves used on the left hand when compared to the right hand, showing $70(51.5 \%)$ and $66(48.5 \%)$, respectively, with $x^{2}=0.310$ and $p=0.577$, without statistical relevance. Therefore, with regard to the perforation index, there is no difference between the gloves used on the left or right hand. No perforations were found on the back of the hands. Instead, the perforations were located on the internal side. The places with the highest perforation indices were the thumb $62(42.5 \%)$, palm $49(32 / 6 \%)$ and index finger with $48(32.0 \%)$, in accordance with Table 2.

Table 2 - Characterization of perforated procedure/surgical gloves during the manual cleaning procedure of PHP by workers from the purging area of a Material and Sterilization Center. Goiânia-GO, Brazil, 2012. $(n=135)^{*}$

\begin{tabular}{|c|c|c|c|c|c|c|}
\hline \multirow{2}{*}{ Perforation sites } & \multicolumn{2}{|c|}{ Right } & \multicolumn{2}{|c|}{ Left } & \multicolumn{2}{|c|}{ Total } \\
\hline & $\mathbf{n}$ & $\%$ & $\mathbf{n}$ & $\%$ & $\mathbf{n}$ & $\%$ \\
\hline Thumb & 24 & 15.8 & 38 & 25.7 & 62 & 42.5 \\
\hline Index finger & 21 & 13.8 & 27 & 18.2 & 48 & 32.0 \\
\hline Middle finger & 16 & 10.5 & 17 & 11.5 & 33 & 28.5 \\
\hline Ring finger & 16 & 10.5 & 12 & 8.1 & 28 & 18.6 \\
\hline Little finger & 7 & 4.6 & 6 & 4.1 & 13 & 8.7 \\
\hline Hand palm & 25 & 16.4 & 24 & 16.2 & 49 & 32.6 \\
\hline Wrist & 3 & 2.0 & 4 & 2.7 & 7 & 4.7 \\
\hline
\end{tabular}

"In total, the number of observations was superior to $n$, as the gloves showed more than one perforation 
Among the gloves analyzed in group A, it was verified that, among the 75 opportunities, in $17(22.6 \%)$, the workers used simple pairs of gloves and $58(77.4 \%)$ gloves on top of gloves. When simple gloves were used, the majority was perforated (13, $76.4 \%$ ) and, when gloves were used on top of each other, it was observed that, in 34 (58.6\%), there were perforations in the external and internal gloves and, in $12(20.6 \%)$, in the external gloves only. In two cases $(3.4 \%)$, the external glove was intact and the internal gloves perforated. No statistical significance was found between the perforation index and the use of simple and overlapping gloves $(p=0.847)$. Concerning perforations, there is no difference when simple or overlapping pairs of gloves are used.

Figure 1 presents the perforations according to the length of use of the gloves after 60,120 and $180 \mathrm{~min}$. Statistical significance was found between the number of perforations and the length of use of the gloves $(p=0.031)$, that is, the longer they were used, the higher the perforation index.

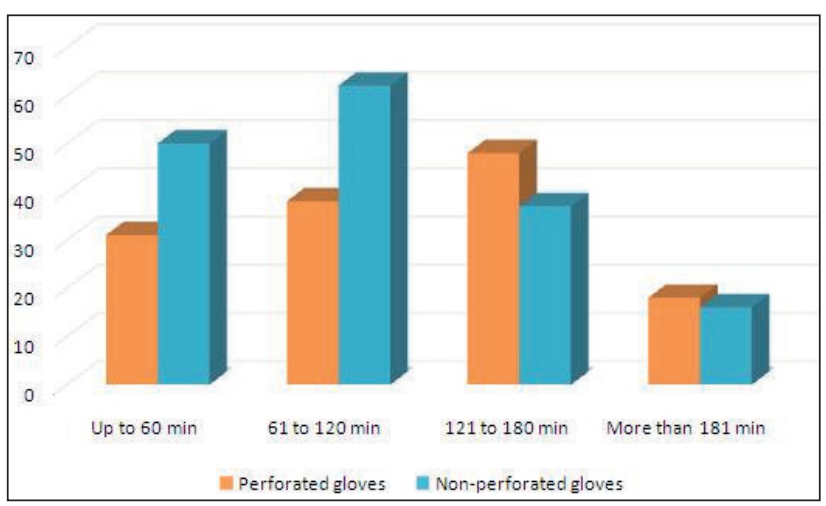

Figure 1 - Distribution of perforation index according to length of usage of the procedure/surgical glove by purging workers after manual cleaning of health products at a Material and Sterilization Center. Goiânia-GO, Brazil, 2012. (n=135)

Among the gloves in group B (100 procedure gloves and 100 surgical gloves from the same brand and size as the gloves in group A), no perforations were found.

With regard to the gloves in group $\mathrm{C}$, among the six new gloves first used at the start of the students' practical activities, three remained intact until the final day of the last practicum group, totaling 48 hours of use $(2,880 \mathrm{~min})$. The remainder revealed perforations and were replaced. The first perforation occurred after six hours of use. In total, 12 gloves were assessed, due to a case of perforation in a replaced glove. Table 1 shows the perforation rates of the gloves in group A according to the type of glove.

\section{DISCUSSION}

Low adherence to the use of nitrile gloves was found for the manual cleaning of PHP, confirming that a reality identified in a study undertaken at the same place of study continued. ${ }^{15}$

The practice of wearing surgical gloves on top of procedure gloves, when compared, showed no statistically significant difference $(p>0.05)$ in the perforation index. Therefore, for the manual washing of the products, both did not offer the worker safety, confirming the contraindication of these gloves for the activity observed..$^{7-8}$

The study demonstrated that, out of 300 gloves analyzed, $45.0 \%$ was perforated. No studies were found in the literature that assessed perforation indices of surgical/procedure gloves in the purging area, probably due to their contraindication, which made it impossible to compare the findings.

Studies of gloves during surgical procedures demonstrated lower perforation indices, ranging between $11.9 \%$ and $16.3 \% .{ }^{18-19}$ This result suggests that washing the PHP entails greater risk for the perforation of surgical gloves than performing surgeries. The need to friction areas with cracks and hinges in the manual cleaning of PHP is well-known, ${ }^{10}$ and that these correspond to the extremities of clamps and scissors, which are sharp, facilitating the perforation of the gloves, which may have contributed to the findings.

Assessments of gloves during surgical procedures showed higher perforation indices on the left hand, ${ }^{19-20}$ which is considered the surgeon's support hand, in line with the present findings that the left is the hand in which the worker holds the PHP for the manual cleaning. The most frequent perforation sites contribute to this understanding, thumb $(42.5 \%)$, palm $(32.6 \%)$ and index finger $(32.0 \%)$.

When analyzing the perforations according to the length of use of the gloves, a significant difference $(p=0.031)$ was found in which, the longer the use, the higher the perforation index. Other studies of surgical gloves also indicate that the length of use interferes, reducing the integrity of the gloves. ${ }^{21-24}$

Concerning the use of multiple gloves found in this study, it was interesting to observe that the highest perforation index happened at the same time, in a case of overlay, in the internal and external gloves. Nevertheless, there are studies that demonstrate the efficacy of using two gloves to reduce the 
risk of contact with blood and secretions in surgical procedures, as the perforations tend to happen more frequently in the external glove only. ${ }^{25-27}$

In one study that verified the perforation frequency in 66 surgical procedures, it was concluded that, in $82 \%$ of the cases, when the external glove was perforated, the internal glove protected the professional's hand. In another study, 1,120 gloves were analyzed, of which 240 pairs were double sets and 880 simple sets. It was concluded that only $2.3 \%$ showed perforations in both external and internal gloves in the double-glove group. Consequently, there was a significantly higher risk for skin and blood exposure in the individual glove sets $(\mathrm{p}<0.01){ }^{29}$

The concomitant perforation of overlapping gloves in this study strengthens the hypothesis raised that the manual washing of PHP represents a greater risk for glove perforation than the surgical procedures, representing risks for the workers. Nevertheless, further studies are needed to confirm this association.

It is interesting to observe the occasions when the internal gloves were perforated while the external ones were intact (3.4\%). This fact arouses suspicions that, in cases of overlay, when a perforation was verified, the worker only removed the external gloves and put new ones over the internal gloves. The study does not permit assessing the potential risk involved, which depends on each situation. Nevertheless, in this condition, organic material may be retained between the pairs of gloves.

The absence of perforations in group B, consisting of new gloves, is similar to a study performed ${ }^{19}$ in which the integrity of the surgical gloves was also assessed before the use. Other studies demonstrated perforation indices $(1.0 \%$ and $1.7 \%)$ deriving from the glove manufacturing process. ${ }^{18,21-22}$

Thick nitrile gloves are recommended for the manual cleaning of PHP. ${ }^{8,11}$ In experimental studies that compared blood transmission through nitrile gloves and simple and double latex gloves through the simulation of piercing-cutting accidents, it was concluded that the nitrile gloves offer greater protection against blood-borne transmission. ${ }^{30-31}$

In fact, it was observed that three nitrile gloves were used subsequently for 48 hours, corresponding to 2,280 $\mathrm{min}$, and could be used longer, as they were discarded at the end of the academic period. Nevertheless, the study showed that the nitrile gloves could also be perforated during the activities performed in the manual cleaning phase. It should be highlighted that the perforations in these gloves were not noticed, as they had already been processed for subsequent use when they were submitted to the leakage test, which can cause a false feeling of safety. These data strengthen the routine recommendation to perform the leakage test with these gloves before each processing. ${ }^{10}$

In view of these study findings, it is considered that the health service managers are responsible for managing their workers' biological risk and, in that sense, that they should make efforts to replace the manual by the automated cleaning method and provide for and supervise the use of gloves appropriate to the risk involved.

Strict legislation exists in Brazil today, requiring the replacement of piercing-cutting material by equipment with safety devices. This is considered an advance, as it divided the responsibility for accidents involving biological material with the employer. In view of the study findings, some questions are raised here: would an automated washer not have the same purpose? Should the replacement of manual cleaning by automated methods not be a requirement for all health services?

Automation would definitely affect the accident rates at MSC and, consequently, would enforce the services' ethical and moral duty to preserve their workers' health. The benefits would by far exceed this aspect and other individual benefits could be mentioned, such as the reduction of the workload at the service; economic benefits like the time spent and the waste of material on manual cleaning; user safety benefits, such as the quality of cleaning using automated methods, which is directly related to the quality of the sterilization.

\section{CONCLUSION}

The predominant use of surgical/procedure gloves was observed for the manual cleaning of PHP, which high perforation indices. The study underlines that procedure/surgical gloves are inappropriate for the manual cleaning process of PHP, constituting an inefficient barrier in the safety of cleaning workers in MSC. Overlaying gloves might grant a false idea of safety, as situations were identified in which the worker used up to four pairs of gloves, all of which were perforated.

\section{REFERENCES}

1. Sarquis LMM, Felli VEA. Recomendações em saúde aos trabalhadores expostos a fluidos biológicos. REME. 2008; 12(3):381-9. 
2. Monteiro CM, Benatti MCC, Rodrigues RCM. Occupational accidents and health-related quality of life:a study in three hospitals. Rev Latino-Am Enfermagem. 2009; 17(1):101-7.

3. Ministério da Saúde (BR). Secretaria de Atenção à Saúde. Departamento de Ações Programáticas estratégicas: exposição a materiais biológicos, Brasília (DF): MS; 2006

4. Tarantola A, Abiteboul D, Rachline A. Infection risks following accidental exposure to blood or body fluids in health care workers: A review of pathogens transmitted in published cases. Am J Infect Control. 2006; 34(6):367-75.

5. Ministério da Saúde (BR). Recomendações para atendimento e acompanhamento de exposição ocupacional a material biológico: HIV e Hepatites B e C. Brasília (DF): MS; 2010.

6. Valim MD, Marziale MPHP. Avaliação da exposição ocupacional a material biológico em serviços de saúde. Texto Contexto Enferm. 2011; 20(Esp):138-46.

7. Ministério da Saúde (BR). Agência de Vigilância Sanitária. RDC n ${ }^{\circ} 15$, de 15 de março de 2012. Dispõe sobre requisitos de boas práticas para o processamento de produtos para saúde e dá outras providências. Brasília (DF): MS; 2012.

8. Sociedade Brasileira de Enfermeiros de Centro Cirúrgico, Recuperação Anestésica e Centro de Material e Esterilização. Práticas recomendadas. $6^{\text {a }}$ ed. São Paulo (SP): SOBECC; 2013.

9. Pinto MB, Vilas-Boas VA, Freitas MIP. Validação do processo de limpeza de artigos odonto-médicohospitalares: uma revisão integrativa. Rev SOBECC. 2013; 18(1):64-72.

10. Association of Operating Room Nurses. Sterilization \& desinfection. Denver (US): AORN; 2013.

11. Psaltikidis EM, Ribeiro SMPC. Recepção e limpeza dos materiais. In: Graziano KU, Silva A, Psaltikidis EM, editors. Enfermagem em Centro de Material e Esterilização. São Paulo (SP): Manole; 2011. p. 62-91.

12. Ribeiro SMCP. Limpeza. In: Padoveze MC, Graziano KU. Limpeza, desinfecção e esterilização de artigos em serviços de saúde. São Paulo (SP): Associação Paulista de Epidemiologia e Controle de Infecção Relacionada à Assistência à Saúde; 2013. p. 57.

13. Ministério do Trabalho e Emprego (BR). Portaria $n^{\circ}$ 485, de 11 de novembro de 2005. NR 32 - Segurança e Saúde no Trabalho em Serviços de Saúde. Diário Oficial da República Federativa do Brasil, 16 nov 2005 [cited 2013 Ago 02]. Available from: http://www. mte.gov.br/legislaçao/normas_regulamentadoras/ nr_32.pdf

14. Tipple AFV, Souza ACS, Almeida ANG, Souza SB, Siqueira KM. Acidente com material biológico entre trabalhadores da área de expurgo em centros de material esterilização. Acta Scientiarum. 2004; 26(2):271-8.
15. Tipple AFV, Aguliari HT, Souza ACS, Severino M, Mendonça ACC, Silveira C. Equipamentos de proteção em centros de material e esterilização: disponibilidade, uso e fatores intervenientes à adesão. Cienc Cuid Saude. 2007; 6(4):441-8.

16. Canalli RTC, Moriya TM, Hayashida M. Acidentes com material biológico entre estudantes de Enfermagem. Rev Enferm UERJ. 2010; 18(2):254-69.

17. Machado E. Avaliação dos testes empregados para deteç̧ão de perfurações em luvas cirúrgicas. Arq Catarin Med. 2008; 37(3):4-8.

18. Solda SC, Assef JC, Parreira JG, Perlingeiro JAG, Candelária PAP, Cury MP, et al. Perfurações não detectadas de luvas em procedimentos de urgência. Rev Assoc Med Bras. 2009; 55(5):597-600.

19. Serratine ACP, Pacheco E, Miero M. Avaliação da integridade das luvas cirúrgicas após a utilização em cirurgias odontológicas. Arq Catarin Med. 2007; 36(1):85-9.

20. Murta EFC, Silva CS, Ferreira NAFD. Perfuração de luvas durante cirurgias ginecológicas. Rev Bras Ginecol Obstet. 2000; 22(4):225-8.

21. Lopes N, Prates N, Rabelo R, Cruz, JFW. Análise da permeabilidade das luvas de látex para procedimento mais utilizadas por alunos da Faculdade de Odontologia da Universidade Federal da Bahia. Rev Ci Méd Biol. 2009 Mai-Ago; 8(2):206-12.

22. Palermo VM, Zimbaldi AM, Martão FF, Teixeira LC, Silva C, Soza A. Evaluation of integrity of procedure gloves used by dentistry students. Rev Gaucha Odontol. 2012; 60(4): 431-36.

23. Palermo VM, Zimbaldi AM, Martão FF, Teixeira LC, Silva C, Soza A. Avaliação da integridade das luvas de procedimento usadas por alunos de odontologia. RGO. 2012; 60(4): 431-36.

24. Partechke LI, Goerdt AM, Langner I, Jaeger B, Assadian $\mathrm{O}$, Heidecke $\mathrm{CD}$ et al. Incidence of microperforation for surgical gloves dependson duration of wear infect Control Hosp Epidemiol. 2009. 30(5):409-14.

25. Misteli H, Weber WP, Reck S, Rosenthal R, Zwahlen $M$, Fueglistaler $P$, et al. Surgical glove perforation and the risk of surgical site infection. Arch Surg. 2009 Jun; 144(6):553-8.

26. Germaine RLS, Hanson J, Gara CJ. Double gloving and practice attitudes among surgeons. Am J Surg. 2003; 185(2):141-5.

27. Naver LPS, Gottrup F. Incidence of glove perforations in gastrointestinal surgery and the protective effect of double gloves: a prospective, randomised controlled study. Eur J Surg. 2000; 166(4):293-5.

28. Thomas S, Agarwal M, Mehta G. Intraoperative glove perforation-single versus double gloving in protection against skin contamination. Postgrad Med J. 2001; 77: 558-60.

29. Na'aya HU, Madziga AG, Eni UE. Prospective randomized assessment of single versus double- 
gloving for general surgical procedures. Niger J Med. 2009; 18(1):73-4.

30. Mansouri M, Tidley M, Sanati KA, Roberts C. Comparison of blood transmission through latex and nitrile glove materials. Occup Med. 2010; 60(3):205-10.
31. Harnob JC, Partecke LI, Heidecke CD, Hübner NO, Kramer A, Assadian O. Concentration of bacteria passing through puncture holes in surgical gloves. Am J Infect Control. 2010; 38(2):154-8. 